\title{
Bullfighting and Masculinity in Jorge Gutierrez's The Book of Life
}

\author{
Leendert Farrel Saimima \& Sri Mulyani \\ mulyanips@gmail.com \\ Universitas Sanata Dharma, Yogyakarta
}

\begin{abstract}
This study is conducted to analyse the masculinity in Jorge Gutierrez's The Book of Life. The study is also conducted to discuss the variety of masculine characteristics within The Book of Life. The film takes place in a little Mexican town called San Angel where the protagonist, Manolo Sanchez, must choose between his family heritage to become the next Sanchez bullfighter or to become himself in his own image. The main objectives of this study are to explore the characters' environmental structure, to distinguish the different characteristics of masculinity between them, and to relate masculinity with bullfighting in The Book of Life. This study uses gender and film approach. Gender approach is used particularly on masculinity since it is the primary discussion in this thesis while film approach is used to aid the researcher to determine where the masculinity is shown in The Book of Life. The method of this research is conducted through film and script analysis. Specific shots and lines from the script are analysed then discussed with the theories regarding masculinity and film.

The result shows that Manolo's masculine characteristics predominantly lies on Male Sex Role Strain, homosexual masculinity, and imposed environment. Meanwhile, Joaquin and Carlos shares the same masculine characteristics; they dominate the Male Sex Role Identity in all four themes and have the same hegemonic masculinity. Though their environment is nothing alike, Joaquin's selected environment and Carlos's constructed environment proved to be more masculine than Manolo. From these, the relations between the masculine characteristics particularly on Pleck's Male Sex Role Identity and bullfighting shows that the various mise-en-scène displays the facial expressions of Manolo and Carlos frequently on scenes where the activity of bullfighting occurred. The framing language is dominated between MS (Medium Shot) and ECU (Extreme Close-Up) shot. Lastly, the continuity editing in The Book of Life is more dominant in the 180o Rule and Shot/Reverse Shot.
\end{abstract}

Keywords: masculinity, gender study, film study

\section{Introduction}

This study discusses masculinity in one of famous blood sports: bullfighting. Bullfighting is a sport where men dare their life in an arena or corrida and put side-by-side with a bull. Their job is to entertain the crowd for a limited amount of time. The peak of bullfighting is when the matadors or bullfighters stabbed the bull to its heart. It is a sport known for its precision kill. Other than it is known for being a deadly form of entertainment, bullfighting is known for its male bullfighter. Males are suited for this deadly profession since they are wellbuilt, brutal, and the proper model for continuing this practice from generation to generation. Relating to men and bullfighting, this study discusses the relation between men regarding what masculinity is and how bullfighting is a part of it. The study is conducted because The Book of Life can be analysed using gender studies, particularly on masculinity. 
Masculinity is chosen due to the presence of diverse perception of what it means to be a man and what makes a man. Through this diverse perception of masculinity as well, this study also discusses the different characteristics of masculinity that the characters have and how these characteristics are shown in The Book of Life.

In order to create an appropriate data and results of the analysis, questions are prepared in this section. They are: (1) what are the masculine characteristics that Manolo, Joaquin, and Carlos have; and, (2) how do the masculine characteristics particularly on Pleck's Male Sex Role Identity theory identify itself with bullfighting?

\section{Masculinity Theories}

The theories about man, masculinity, and environment are explained and mentioned in this section. Obsessive Competitiveness discusses how men competes between one another to confirm their masculinity while Male Sex Role Identity and Sex Role Strain relates one another with Hegemonic Masculinity and Homosexual Masculinity in terms of how these men are qualified as "real man" or not. Lastly, Environmental Structures describes the situation or environment that a person experienced in developing his masculinity.

\section{a. Obsessive Competitiveness}

Obsessive Competitiveness is a part of male stereotype that relates men on their masculinity on a basis of labour division and distinguishing sex roles, thus affecting in everything they do. For example, men hardly have time relating to children because of the inflexible nature of their masculine personalities. Because of men's perception of their personality, assuming superior, reasoned male logic, a child's emotional needs seem frustrating, annoying and sport is the only way to build character. Even as spectators, men vicariously identify with performing athletes in such a way as to strengthen their masculine identities through intelligent observation and by plotting counter-strategy (Dubbert, 1979: 4).

\section{b. Male Sex Role Identity and Sex Role Strain}

Male Sex Role Identity is a concept from Joseph Pleck that conform the idea of "real man". To achieve "real man" state, there are four mandatory themes in order to acquire the state. The four themes are:

i. No Sissy Stuff: The stigma of all stereotyped feminine characteristics and qualities, including openness and vulnerability.

ii. The Big Wheel: Success, status, and the need to be looked up to.

iii. The Sturdy Oak: A manly air of toughness, confidence, and self reliance.

iv. Give 'Em Hell: The aura of aggression, violence, and daring.

Pleck also propose Male Sex Role Strain, a concept that differentiates itself from Male Sex Role Identity. Its occurrence exists as a result of men's inability to achieve the "real man" state and questioned the desirability of Male Sex Role Identity (Brannon, 1996: 170-172).

\section{c. Hegemonic Masculinity and Homosexual Masculinity}

Hegemonic masculinity is the cultural dominant ideal of masculinity centred on authority, physical toughness and strength, heterosexuality and paid work placed on top. Hegemonic masculinity is placed on top of the "gender hierarchy" structure for its characteristics. Homosexual masculinity is a form that includes a range of masculine behaviour which does not fully match up to the macho ideals of hegemonic masculinity. Homosexual masculinity is referred to as "subordinate masculinities" due to its unachievable feat in living up to the hegemonic masculinity standards (Pilcher and Whelehan, 2004: 83-84).

\section{d. Environmental Structures}

Environmental Structures is a part of social cognitive theory that is not a monolithic entity disembodied from personal agency. Environmental Structures are distinguished into three types; imposed environment, selected environment, and constructed 
environment. An imposed environment is an environment where certain physical and sociostructural conditions are thrust upon people whether they like it or not and it is occurred that though they have little control over its presence, they also have leeway to respond and to react towards it. Selected environment refers to the notion of potential environment that the people choose to have on their own terms. By choosing a selected set of environments, people have different paths towards development in society. Constructed environment is an environment where people constructed social environments and institutional systems through generative efforts. A prime example of constructed environment is children's symbolic play of role learning (Bussey and Bandura, 1999: 14-15).

\section{Film Theories}

This section includes mise-en-scène which explains how a scene or shot carry meanings through specific Framing Language within that shot and how the settings are made spatial, spacious, and sequential using Continuity Editing.

\section{a. Mise-en-scène}

Mise-en-scène is a term originated from the theatre and it refers to staging, or "putting on stage" (Benyahia, 2006: 18). In film studies, mise-en-scène often has a vague meaning: it is either used in a very broad way to mean the filmed events together with the way those events are filmed, or it is used in a narrower sense (closer to its original theatrical meaning), to designate the filmed events (Buckland, 1998: 8).

Another definition of mise-en-scène is the theatrical process of staging. It retains the theatrical overtones, meaning to "put into the scene" and designating all that encompassed by the frame (Villarejo, 2007: 28). To make it into a comprehensible sentence, mise-enscène is a study of the relation between subject matter style (the relation between what and how). It may focus on the relation between how the cuts from shot to shot relate to the action and dialogue (Elsaesser, 2002: 80). There are six elements in mise-en-scène such as setting (set and props), lighting, costume, hair, make-up, and figure behaviour (Villarejo, 2007: 29).

\section{b. Framing Language}

Framing language refers to the use of camera's movement and angle to create a certain image within a frame. Every placement of the camera can be analysed in terms of the distances between the camera and its object(s) (Villarejo, 2007: 38). There are seven types of framing based on their distances. Using the human body as reference point for each designation, they are:

i. The Extreme Long Shot, a framing that is taken far from its object(s). The human body is usually unrecognisable in this shot.

ii. The Long Shot, a framing in which the human body is recognisable but small compared to the background.

iii. The Medium Long Shot, this shot is taken only from the knees up within a frame.

iv. The Medium Shot, this shot goes all the way from the waist up within a frame.

v. The Medium Close-Up, a shot that moves a bit closer from the chest up of the human body.

vi. The Close-Up, the shot that removes most of the human body and left nothing but the face.

vii. The Extreme Close-Up, this last shot puts only a mere part of the face such as an eye or the lips. For practical reason, all of the types are abbreviated later in the analysis as ELS, LS, MLS, MS, MCU, CU, and ECU.

\section{c. Continuity Editing}

Continuity editing is used to create a seamlessly continuous space between shots. This creates a sequence among the shots. A sequence will typically begin with a shot which establishes a location for the characters, before focusing upon one or more of them and their actions (Butler, 2005: 24). Shot/reverse shot, the $180 \mathrm{o}$ Rule, and the $30 \mathrm{o}$ Rule contributes to the continuity editing scheme. The 180 o Rule enables the viewer to maintain a sense of continuous space within a location is to avoid any shots that might apparently reverse the posture of the characters. This is achieved by imagining a line running across the set or 
location, over which the camera cannot cross (Butler, 2005: 26).

\begin{tabular}{|c|}
\hline $\begin{array}{c}\text { SETTING/LOCATION } \\
\text { The imaginary line }\end{array}$ \\
\hline CAMERA \\
\hline
\end{tabular}

A shot/reverse shot is where the camera focus upon a face, either head-on or to one side, and then to cut to either what they can see or to a shot peering over their shoulder (Butler, 2005: 25). The $30^{\circ}$ Rule is used to ensure that there is a sufficient differences in shots. To maintain a continuous space, the camera is limited as to where its next shot can come from (Butler, 2005: 27).

\section{The Masculine Characteristics of Manolo, Joaquin, and Carlos}

\section{Manolo’s Masculinity}

Manolo Sanchez is the son of Carlos Sanchez and the last descendant of the Sanchez bullfighters. In The Book of Life, Manolo is expected to become the bullfighter his father wishes to be. However, this is against his will. Manolo's constant struggle to overcome his fear led him to construct his masculinity. Manolo's masculinity is developed through two characters; Carlos Sanchez and Joaquin.

CARLOS SANCHEZ. Well, fathers do what's best for their children. Come along. Mijo, I saw how you fought that beast. You made our ancestors proud. MANOLO. Do you think Maria was impressed?

CARLOS SANCHEZ. Maria and every girl in town. People said I was the greatest bullfighter in our family's history... But it is you, my son, who will be the greatest Sanchez ever! They will write songs about you! MANOLO. And I will sing them!

CARLOS SANCHEZ. Wait, what?

MANOLO. I will sing them.

CARLOS SANCHEZ. Son, music is not work fit for a Sanchez bullfighter.

MANOLO. But I want to be a musician. CARLOS SANCHEZ. No. You must focus. Your training begins at once. Your grandpa, Luis, taught me when I was about your age.

MANOLO. Wait, isn't that when that bull put you in a coma?

CARLOS SANCHEZ. Memories. My only son fighting angry, thousand- pound beasts. The family tradition continues (Gutierrez, 2014: 5).

The conversation shows Carlos's disagreement with Manolo's decision. Manolo places himself as the "subordinate" male due to his unachievable feat to live up the standard of the Sanchez family name. At first, Manolo's decision to become a musician is purely from his own thought from the start. In The Book of Life, the town of San Angel has only one bullfighting family; the Sanchez. By becoming the only bullfighting family, Carlos sees Manolo as the next heir of the Sanchez bullfighter and the arena where his family performs their deadly fiesta. From the beginning, Manolo has his own interest to play guitar and to sing for Maria. The opening of The Book of Life starts with scenes Manolo, Joaquin, and Maria at their young age playing together and creating havoc in the town hall.

Manolo and Joaquin save the day by joining forces to clean up their mess. One particular mess that they did was releasing a horde of hogs and marching them towards the town hall where General Posada, Maria's father, is there to recruit men to protect the city from Chakal, the bandit king.

This part of mess is taken care by Manolo mostly. He grabs a red scarf and taunts the massive hog that is in the middle of the hall. His execution is excellent and Carlos sees this as a sign that Manolo is capable to become the next Sanchez bullfighter. After Manolo saves the day, Carlos showed him the arena while having a conversation about how Manolo could become the greatest Sanchez bullfighter, exceeding his father. Carlos tells him that if he can become the greatest bullfighter ever, the people of San Angel will sing him a song, knowing that this way Carlos can persuade Manolo to follow the family tradition of bullfighting.

However, Manolo considers being a bullfighter not as a passion, but as a way to 
enhance his own passion. That is why he wanted to sing the songs that the people of San Angel write for him. His father disagrees with his decision and tells him that a musician does not belong to the Sanchez traditional bullfighting family and demand Manolo to focus on the task ahead. Using the theory of environmental structure, Manolo faces the struggle of living in an imposed evironment where he has little control over what he is capable to do or not in his life. This early warning gives Manolo a look up upon what he will face later in his adult stage later.

Years passed and Manolo becomes a grown man still yearn for becoming a musician. In this part of conversation, Manolo is in the town hall singing with the mariachi brothers "I Will Wait For You" that is meant for Maria. Right in the ending of the song, Carlos yanks Manolo and drags him to the arena. Carlos is dissatisfied with Manolo's behaviour of not being a proper Sanchez bullfighter.

After dragging him, Carlos puts him in a room where grandma is there knitting her yarn and pictures of the late Sanchez bullfighters as well as Carmen Sanchez, Manolo's late mother, are placed on the wall. Carlos then enters the room, grab Manolo's guitar, throw it to the corner of the room, and equip his son with two swords while saying:

CARLOS SANCHEZ. Quiet, you lazy bums! You live under my roof. You live under my rules. You will be a matador!

MANOLO. Papa, this is my life (Gutierrez, 2014: 6).

The conversation states Carlos's lack of empathy towards Manolo's decision in life. Throwing the sword to the door where the mariachi brothers' stand proves that Carlos is not happy with the presence of other "subordinate" male around him and his son. This implies Carlos's intention to have Manolo to learn that being male they need to be rough from time to time.

Again, this also places Manolo in an imposed environment; only this time with a minor struggle. Due to his current appearance as an adult, Manolo is freely to choose his way of life using selected environment. Mariachi band are a group of men that plays music with string instrument such as violin, cello, and guitar. The men play various kind of music and entertain the crowd. In The Book of Life, Manolo chooses this kind of environment since his nature as a son or as a man does not really attached to the whole "gender hierarchy" notion. To prove his state and to hold his own believe, he insists that he could never hurt a bull in front of his own father. He states:

MANOLO. No. Killing the bull is wrong.
CARLOS SANCHEZ. Here we go again.
GRANDMA. Kids today, with their long hair
and their no killing stuff.
MANOLO. I'm out of here
(Gutierrez, 2014: 7)

For him, killing an animal just for the sake of entertainment and for proving that he is "a true Sanchez man" is not worth the kill. This shows Manolo's stand as he lives up to the notion of Male Sex Role Strain.

In the art of bullfighting, a bullfighter must endure the thrill of "guiding the bull to its death". The thousand-pound beast will not so easily give up its life to a man, rather not a bullfighter. However, in The Book of Life, there is no "guiding" like a bullfighter should commonly do. Instead, Manolo, again, stands firm with his own opinion to not kill the bull, yet this time he states his opinion in the middle of the arena with hundreds of people watching him. This enrages the crowd and they throw stuff at him, even his own guitar that eventually knocks him out due to the impact to the head. Carlos immediately wakes the sleeping son with a stern tone. Momentarily after waking up, Manolo states that:

\section{MANOLO. If being a bullfighter means... it means killing the bull... Well, then, I'm no bullfighter. \\ CARLOS SANCHEZ. No. You are no Sanchez (Gutierrez, 2014: 8)}

This assures Manolo's position as the "subordinate" male since he cannot live up to Carlos's Male Sex Role Identity in terms of being brute, fearless, and merciless. His father's statement also automatically establishes Manolo in a position of Male Sex Role Strain as his acknowledgement to Manolo's lack of desire to become a "real man". 
Unable to live up to his father's demand, Manolo ends up being branded as the weakest member of the Sanchez bullfighter. He is the opposite of what a bullfighter's characteristics should have. Though Carlos's persistent lecture on what it takes to be a man bothers him regularly, Manolo prepares his cape as he marches on competing with Joaquin, who is now the current hero of San Angel.

JOAQUIN. Hey, Manolo! No retreat.

MANOLO. No surrender. The hero of San Angel returns!

JOAQUIN. Oh, come on. You didn't think I was gonna miss your first little bullfight, did you? MANOLO. And Maria's here, too!

JOAQUIN. Have you seen her? I cannot wait to show her these babies.

MANOLO. So, she's back only to see you? JOAQUIN. Come on. That's not...

MANOLO. You have your medals, but I have the bullring. We'll see which Maria prefers. JOAQUIN. It's a good thing you're finally taking bullfighting seriously.

MANOLO. You should see me in the bullring. That's where I really do my thing now. A true Sanchez man. (Gutierrez, 2014: 7)

This states Manolo's hegemonic masculinity since Joaquin is present and he wants to show what Carlos has thrusted him upon through training years before. In summary, he did not want to become a "subordinate" male when it comes to competing with Joaquin. In this certain case Manolo for the first time, as an adult male, displays Pleck's Male Sex Role Identity particularly on the Sturdy Oak theme. The parts where he "really do my thing" and tells Joaquin that he is "a true Sanchez man" evokes the nuance of toughness, confidence, and selfreliance that every Sanchez bullfighters have.

When the time comes for Manolo to enter the corrida, Joaquin is already seated in a podium with General Posada waiting for Maria's arrival. Manolo welcomed the return of senorita Posada by dedicating the corrida to her. After that, the bull marches from the other side of the arena and Manolo begins the bullfighting.
In his first bullfight, Manolo impresses the crowd, Carlos, and Maria. The crowd cheers to Manolo Sanchez as he executes the show flawlessly. The peak of his finest execution is when he lures the bull back and forth, round it over and over, then finally creates a pile of dust that when Manolo swept it with his cape, the sand which has been carved by the bull's horn shows Maria's name on it. This action that Manolo performs is part of obsessive competitiveness. Manolo executes this part successfully and thus building up his masculinity to impress Maria.

Near the end of the match, Manolo does not finish what Carlos and the crowd expects him to do; kill the bull. Seeing Maria's face from the sword's reflection made him realise that he cannot be as the same as the other bullfighters. The match ended in disappointment and Carlos understands that Manolo is not the Sanchez bullfighter he expects him to become. The day passed and at night General Posada holds a grand party to welcome Maria back, which turns out to be a disaster and led Maria going to her room. In this scene, Manolo is accompanied by the mariachi brothers. They cheered him up by helping him get Maria through singing. One by one the brothers fail to do so and left Manolo for a meal. Manolo then steps in and sing "I Love You Too Much" which lulls his surrounding and invites Maria to step outside of her bedroom. The moment is set and it may seem that Manolo will get her, but in the end, he falls down and becomes unconscious. Maria comes down and finds Joaquin proposing her. Manolo comes into the scene thanks to the support of Pepe Rodriguez, one of the mariachi brothers. Manolo, who is still unconscious, approaches Joaquin and they begin to quarrel.

MARIA. Did you think it was gonna be that easy?

MANOLO. I... I kind of did.

MARIA. Manolo! Hold on, I'm coming. Joaquin. What are you doing?

JOAQUIN. Maria... will you... will you marry me?

THE GIRLS. Yes.

JOAQUIN. Don't worry, your father already said you could.

MARIA. He did... what? 
GENERAL POSADA. Who else could protect us from Chakal?

MANOLO. What did I miss?

JOAQUIN. Wait... wait a sec. Did he propose, too? MARIA. No. Were you going to?

MANOLO. What?

JOAQUIN. Well, I proposed first. So, go fight a bull or something.

MARIA. You two are acting like fools!

MANOLO. Wait, me too?

DALI 4. You're so strong, Joaquin.

JOAQUIN. Thanks, I work out a lot. Look, I love you, you know that. But how are you going to protect Maria if you can't even finish a bull? DALI 4. Good one, Joaquin!

MANOLO. Oh, yeah? Well, you will never be as great a hero as your father! DALI 4. Now,. that's just uncalled for (Gutierrez, 2014: 11)

Though at first Manolo displays a "real man" state on the conversation with Joaquin before, this current conversation shows his Sex Role Strain when he compares Joaquin with his deceased father, Captain Mondragon. Manolo's current Sex Role Strain breaks the notion of No Sissy Stuff that includes all stereotyped feminine characteristic, such as comparing.

Manolo's comparison shows his lack of maturity on finding faults in Joaquin's great feat as hero of San Angel. In The Book of Life, Joaquin follows his father's footstep. As a son, it is natural that he wishes to become just like his father. After the quarrel ends, Chato and the other bandits raided the town. Manolo, General Posada, and Maria who are in the town hall receives help from Joaquin to made the bandits retreat.

\section{CHATO. Retreat!}

JOAQUIN. And don't ever come back! MARIA. Yeah! You better run away! That was incredible.

MANOLO. Yeah, you really are a hero. (Gutierrez, 2014: 12)

The conversation states Manolo's Sex Role Strain in terms of admitting that Joaquin is better than his father and better than himself when it comes to physical strength. Thanks to Xibalba's medal of everlasting life, Joaquin leaps up to the "gender hierarchy" faster than
Manolo. Manolo's masculine characteristics does not live up to the idea of men in general. Though in certain cases Manolo can show his masculinity, when it comes to himself Manolo is incapable to become a proper man. Even the lad with betterthan-average endowments also suffers if those endowments happen to be in areas not included in the culture's definition of what is "masculine" - music, for example, or art (Pleck, 1974: 10).

\section{Joaquin's Masculinity}

Joaquin is the hero of San Angel and a friend to Maria and Manolo. In The Book of Life, Joaquin is the son of the late Captain Mondragon, a friend to General Posada and the former protector of San Angel from the bandit king. Though Joaquin does not become a bullfighter, his masculinity proves to be ostentatious than Manolo. With the love-andhate relationship between Manolo and Joaquin for Maria's hand in marriage in The Book of Life, Joaquin presents numerous obsessive competitiveness acts to encourage Manolo to seek out his inner masculinity.

JOAQUIN. Hey, Manolo! No retreat.

MANOLO. No surrender. The hero of San Angel returns!

JOAQUIN. Oh, come on. You didn't think I was gonna miss your first little bullfight, did you? MANOLO. And Maria's here, too!

JOAQUIN. Have you seen her? I cannot wait to show her these babies.

MANOLO. So, she's back only to see you? JOAQUIN. Come on. That's not...

MANOLO. You have your medals, but I have the bullring. We'll see which Maria prefers. JOAQUIN. It's a good thing you're finally taking bullfighting seriously.

MANOLO. You should see me in the bullring. That's where I really do my thing now. A true Sanchez man.

JOAQUIN. Those are some big shadows we live under, buddy?

MANOLO. Huge.

JOAQUIN. Hey, brother, may the best man win Maria. (Gutierrez, 2014: 7)

In the conversation, Manolo's masculinity is developed and it is already discussed in the 
previous subchapter. Through this conversation again, it can be seen that after departing for so long, Joaquin shows up with glittering medals covering his whole chest. This shows just how much duty Joaquin has accomplished over the years travelling from town to town sweeping bandits away. The medals proved that he fulfils all the necessary needs from Pleck's four themes of Male Sex Role Identity to become a man.

Joaquin's word to Manolo also dares him to become better than before since he proclaimed to Joaquin that he is a "true Sanchez man". This puts Manolo in the same manly state with Joaquin. By using obsessive competitiveness, Joaquin encourages Manolo to ensure himself that he is a real "manly" man. In the perspective of environmental structure, both Joaquin and Manolo are in the selected environment. However, Joaquin's selected environment is also a part of constructed environment.

In The Book of Life, the role of hero as protector is crucial since only a hero can save the town from bandits. Joaquin's primary role is to protect and to help to those in need, just like his father. Unlike his father, Joaquin receives help from Xibalba to boost his strength and courage. By giving the medal of everlasting life, Joaquin is granted the power of what other men cannot have. This also makes him so strong that he can withstand the immense power coming from the massive hog that he handled head-on back when he was young. Another occurrence where Joaquin dominates Manolo is when he goes on a quarrel with Manolo. This time, Joaquin bring out Manolo's weakness in front of everyone.

MANOLO. What did I miss?

JOAQUIN. Wait... Wait a sec. Did he propose, too?

MARIA. No. Were you going to?

MANOLO. What?

JOAQUIN. Well, I proposed first. So, go fight a bull or something.

MARIA. You two are acting like fools!

MANOLO. Wait, me too? DALI 4. You're so strong, Joaquin.

JOAQUIN. Thanks, I work out a lot. Look, I love you, you know that. But how are you going to protect Maria if you can't even finish a bull? DALI 4. Good one, Joaquin! (Gutierrez, 2014: 11)

The conversation states that Joaquin uses hegemonic masculinity and Male Sex Role Identity against Manolo. Joaquin believes that if Manolo cannot even handle a single bull he is not certain that Manolo can protect Maria from harm and this is proved later in the film that he actually cannot protect Maria from getting bitten by Xibalba's two-headed snake staff.

Though it is taunting and breaking the No Sissy Stuff theme, in Joaquin's perspective, the words that he utters do not have any element of comparing or anything that is considered a part of the theme since he told the truth about Manolo's deficiency on aggression. To Joaquin, men are programmed to be "strong" and "aggressive" (Pleck, 1974: 42).

In The Book of Life, Joaquin is the hero that anyone looks up to. He saves the town from bandits and wakes Maria up from her comatose state. Everything seems great for the hero until Chakal marches towards San Angel to repossess the medal of everlasting life. $\mathrm{He}$ takes the medal from Joaquin with ease and turns him into a mundane man with no superhuman-being like strength. While Joaquin is defeated, Manolo is granted life by the three rulers of realms; Candle Maker, La Muerte, and Xibalba. He accomplishes the task set by Xibalba that permits him to live again. Later, after Manolo returns to San Angel, the trio (Manolo, Maria, and Joaquin) along with the people of San Angel as well as the whole Sanchez family join forces and stop Chakal from destroying the town. In the end, he is defeated, but with a sacrifice. Manolo sacrifices his life to save the town he holds dear. When the whole town thinks that he has gone, he appears unharmed and rejoices with Maria. The reason why he did not die is because of Joaquin.

MARIA. Joaquin.

MANOLO. You gave me the medal. You were going to sacrifice yourself... for me.

JOAQUIN. I thought it might be time... to be a true hero. Like you, Manolo.

MARIA. Are you all right?

JOAQUIN. I've never seen more clearly. It's time to cast our own shadows. 
MANOLO. And write our... our own stories. (Gutierrez, 2014: 24)

This ends the duel between Manolo and Joaquin and terminates the loveand-hate relationships between them. From the fight, Joaquin realised that he can become a man in his own ways, without any magic medal to help. Joaquin's masculine characteristics predominantly lives up to the notion of tough men. He is aggressive, tough, and has a status that anyone looks up to. This shows that he has what it takes to be a 'real' man. From child, he becomes a part of General Posada's men, after noticing that he saved him from a raging hog.

Over times, Joaquin's masculinity escalades as his mental and body grows from a child to a man. Reaching this stage has perfected Joaquin's masculinity that it fulfilled the 'real man' state and also constructed Manolo's masculinity and vice versa.

\section{Carlos's Masculinity}

Carlos Sanchez is the father of Manolo Sanchez and the epitome of the Sanchez's family masculinity, being the last descendant of a bullfighter that actually finishes the bull. In Carlos definition of masculinity, men are not suited for sensitive and openness stuff. In The Book of Life, Carlos persuades Manolo to become a bullfighter. Carlos's environment is predominantly linked with the constructed society of Mexican tradition, primarily in the notion of toughness and bravery. In a scene after Manolo saves the day from the angry hog, Carlos invites Manolo to take a walk through a small alley where they stopped in front of a fence with the setting of the arena and the sunset as the scenery. This scene shows that the corrida is where every Sanchez bullfighters prove their supremacy over fear. This particular scene also demonstrates the idea of where this blood sport is considered a tradition and raw strength meet. In The Book of Life, Carlos is predominantly in the constructed environment. The notion of bullfighting as a call and as an honour still lives up in Carlos's life. That is why he encourages Manolo to do so. The idea of constructed environment is that through efforts and generative way, the certain idea of what is "masculinity" can be constructed repetitively.
Another nuance of constructed environment can also be seen when Carlos explains to Manolo that he is a Sanchez. In a room where Manolo is dragged by Carlos, he performs what any father would do to their child; being in control.

CARLOS SANCHEZ. All the Sanchezes are bullfighters! Every single one of us. GRANDMA. I was a beast in the arena. A beast! CARLOS SANCHEZ. It's in your blood. It's your destiny. How many times do I have to say it? MANOLO. This is not me. This is you.

CARLOS SANCHEZ. My son, Joaquin may be the hero of the town but today, you will be the hero of the ring. If, for once, you actually finish the bull (Gutierrez, 2014: 6).

Through the conversation, it is clearly seen that Carlos stresses Manolo on the importance of bearing the family name. In the system of constructed environment, the notion of masculine men in the Sanchez family recognisable from their performance in the arena. The performance that they executed inside the corrida determines whether or not the matador is worth to be called a Sanchez or not. Carlos's utterances of "it's in your blood, it's your destiny" conforms the idea that masculinity is a heritage and something that Manolo should accept willingly. The greatest honour of all Sanchez bullfighters is that they are known to be brute and tough. In The Book of Life, the former Sanchez bullfighters are all recognised by their performance in the corrida. Take for example Luis "El Super Macho" Sanchez. Luis is Manolo's grandpa and is renowned for fighting three bulls at once. In a scene that has been discussed earlier where Carlos shows Manolo the spectacular view of the arena covering the sunset, Luis Sanchez is mentioned as a reference to Carlos's old memories. This explains why constructed environment is adamant in the Sanchez household and it is because they have their own terms of what is "masculine".

Another masculine attribute that Carlos uses on Manolo is the use of obsessive competitiveness that he puts on Manolo against Joaquin. To make Manolo obey Carlos, he urges Manolo to remember that Joaquin is ahead of him in terms of being recognise as a 
hero. While raising a sword and a statement, Carlos sharpens his words so that Manolo understand that he must become a hero as well. The meaning of hero in here refers to what every bullfighter must do; killing a bull. Carlos uses obsessive competitiveness as means of nurturing Manolo. Fathers buy into the myth of sons being an extension of themselves as they wish to be seen by the world (Pleck, 1974: 275). By using obsessive competitiveness, he believes the idea of Manolo as an extension of himself like he is the extension of Luis "El Super Macho" Sanchez. As any father would want for their children, Carlos wanted Manolo to become the greatest Sanchez bullfighter ever lived. Though Manolo disagrees with his idea and backed away, Carlos lures him back with words that even Manolo cannot neglect.

\section{MANOLO. I'm out of here.}

CARLOS SANCHEZ. Don't you love your family? Then go get that bull, mijo. Don't dishonour our name. Just be a Sanchez!

GRANDMA. Mijo... he no gonna do it. (Gutierrez, 2014: 7)

The sentence "Don't you love your family?" halts Manolo from leaving the room. Using family as a medium to get his son back on track shows Carlos's practicality to alter Manolo's rebellious thoughts. Since conventionally, strength, silence and being control are the hallmarks of being a father. Men are described as being unable to express their emotions, competitive, brutal in the way they use their muscular strength, and incapable of showing intimacy, apart from during sexual contact (Salisbury and Jackson, 2004: 274).

From what Salisbury and Jackson have mentioned, Carlos's words have sustained Manolo enough that he should comprehend it individually and realise that he is a Sanchez bullfighter by blood. In The Book of Life, it is clearly noticeable that Carlos frequently reminds Manolo to "be a Sanchez". One particular utterance from Carlos is when he handed Manolo a sword from the edge of the arena for him to execute the bull. He utters "Come on, mijo. For me. For our family. Be a Sanchez!" as a sure and a final warning that Manolo should not mess up the corrida along with Carlos's hope. Despite of what Carlos has said and done to teach Manolo the vital meaning of being a bullfighter, Manolo did not kill the bull. Infuriated by Manolo's performance, Carlos denounces Manolo as weak, inferior, and unworthy to be called "a Sanchez".

\section{CARLOS SANCHEZ. Manolo. Manolo. Get up! MANOLO. I'm sorry, Papa. \\ CARLOS SANCHEZ. Do not make it worse by apologizing! A Sanchez man never apologizes! Never! \\ GRANDMA. Ever. \\ MANOLO. If being a bullfighter means... it means killing the bull... well, then, I'm no bullfighter. \\ CARLOS SANCHEZ. No. You are no Sanchez.} (Gutierrez, 2014: 8)

Though the conversation has been discussed previously, the following analysis refers to Carlos's act of denoting Manolo's masculinity. The repetitive utterance "be a Sanchez" that Carlos relentlessly give to Manolo is actually an embodiment of Male Sex Role Identity that every bullfighter in the Sanchez family ever have. It is by then the ultimate teaching that Carlos set forth to Manolo so that he can become greater than his father, though in the end Manolo did not live up to it.

The disappointment does not end there. After Manolo's trivial mishap in the corrida, Carlos have to hold the burden and the shame knowing that his son fails him in and out of the ring.

CARLOS SANCHEZ. Failing in and out of the ring. The whole Sanchez family would be so disappointed in you.

MANOLO. Please, don't say that.

CARLOS SANCHEZ. Listen. You love Maria? Then fight for her, like a man!

MANOLO. It's too late. Joaquin proposed to her already.

CARLOS SANCHEZ. Now, that's a real man. GRANDMA. Quiet, Carlos! Manolo, if Maria didn't say yes to Joaquin... then she said no. CARLOS SANCHEZ. So, what are you gonna do about it, son? (Gutierrez, 2014: 12) 
To Carlos, what concerns him is that Manolo did not do very well to impress his father as well as his ancestor. The constructed environment that the Sanchezes have are meaningless compared to Manolo's selected environment. Carlos advises Manolo the last time that if he cannot "be a Sanchez" in the corrida, at least he can become a man outside the ring - he urges Manolo to fight for Maria. Manolo, dwelling in his homosexual masculinity, mutters over the loss of Maria to Joaquin. While he is being pessimistic about Maria, grandma gives him hope and soon after hearing her advice, Manolo rushes himself to meet Maria and they end up meeting at a big tree just outside of San Angel. This is where Maria goes to a comatose from getting bitten by Xibalba's two-headed snake staff. Manolo, in pain, accepts Xibalba's offer and wakes up in The Land of The Remembered. Xibalba tricked Manolo into believing that he can grant Manolo's wish; to be with Maria. After knowing that Xibalba cheats his way out to become the ruler of the realm, Manolo and his family sets out to meet La Muerte who is the current ruler of The Land of The Forgotten. With the help of Candle Maker, Manolo is able to meet La Muerte and exposed Xibalba's treachery.

After hearing Xibalba's grimy deed, La Muerte summons Xibalba and persuade him to give Manolo a chance to live again. Xibalba accepts it under a condition. He and the others are then transported to an arena in The Land of The Remembered. Xibalba challenges Manolo to finish all the bulls that the Sanchez bullfighters had ever executed all at once. If he succeeded, he will be granted life and if he failed, he will be forgotten. While Manolo struggles to defeat the bulls, Carlos ends up dead from protecting San Angel from Chakal. Carlos appears in a podium where the Sanchezes watches Manolo in the corrida. With the whole Sanchez family on the same podium witnessing Manolo, the match become intense as the bulls round themselves on the other side of the arena and create a gigantic oversized bull that even Manolo cannot handle.

The massive bull charges itself towards Manolo. Manolo escapes the raging bull and the bull crashes into the wall, making it out cold. Manolo is swept due to the immense aftermath of the bull's body charging towards the hard wall. He then wakes up with a wound, walks to the sword, and sees his own reflection. The whole Sanchez family anticipates the moment that Manolo will execute the bull for his life. Instead, Manolo grabs the guitar lying next to the sword and sings "The Apology Song" to the bull. Though the bull harms him even more, Manolo's resilience eventually calmed the fearsome beast. The bull gives in to Manolo's lullaby and it disappear in thin air. Xibalba realise that Manolo is not hesitant about killing a bull, but it is about being himself. As Manolo finishes with the bull, the whole Sanchez family goes to him and cheers for him. Carlos did not expect that singing can help Manolo overcome the bull. Carmen, Carlos's wife and Manolo's mother, tells him that "He is a Sanchez". This is the very word that Carlos uttered before to Manolo, and now is given to him by Carmen.

CARLOS SANCHEZ. But how did Manolo do this?

CARMEN SANCHEZ. He's a Sanchez.

MARY BETH. Xibalba had been wrong. Manolo's fear was never bullfighting.

CARLOS SANCHEZ. I told you, a Sanchez man never apologizes.

MANOLO. Papa, I...

CARLOS SANCHEZ. But you just changed that. I should have been a better father. I am very sorry.

MANOLO. No. You only wanted what was best for me.

CARLOS SANCHEZ. I'm so proud of you, son. MANOLO. I love you, Papa.

CARLOS SANCHEZ. Ay, mijo.

MARY BETH. And at that moment, Manolo conquered his greatest fear... being himself (Gutierrez, 2014: 22).

The moving conversation shows Carlos's flaw as a father. He realises that bullfighting is never the answer for masculinity. Though fathers in general seem to be perceived as punishing or controlling agents (Pleck, 1974: 8), Carlos, in the end, accepts Manolo's decision fully without being indecisive about it. In general, Carlos's masculine characteristics are quite the same with Joaquin. He is rough and insensitive towards Manolo. He may be rude, but that is just how fathers normally do to their sons. The reason is that they want their sons to victor over others, even themselves. The notion of obsessive competitiveness, Male 
Sex Role Identity, hegemonic masculinity, and constructed environment are all the tools and attributes they need to nurture their young into strong, competent, and resilient in order to be called "man".

\section{Masculine Characteristics of Pleck's Male Sex Role Identity Theory and Its Identification with Bullfighting}

The application of Pleck's Male Sex Role Identity theory is discussed here using film theories. In this subchapter, the application of Pleck's theories is analysed using mise-enscène, framing language, and continuity editing. Before the analysis continues further, this subchapter merely discusses the relation of how the masculine characteristics particularly on Pleck's Male Sex Role Identity theory are identified with bullfighting through series of shots and frames. The researcher only analyses the shots and frames in The Book of Life that are related with bullfighting and Pleck's Male Sex Role Identitiy theory.

In The Book of Life, the first mise-en-scène of Pleck's Male Sex Role Identity is a CU shot where Manolo faces the angry hog. The $\mathrm{CU}$ shot reveals Manolo's facial expression when he taunts the hog that is coming towards him.

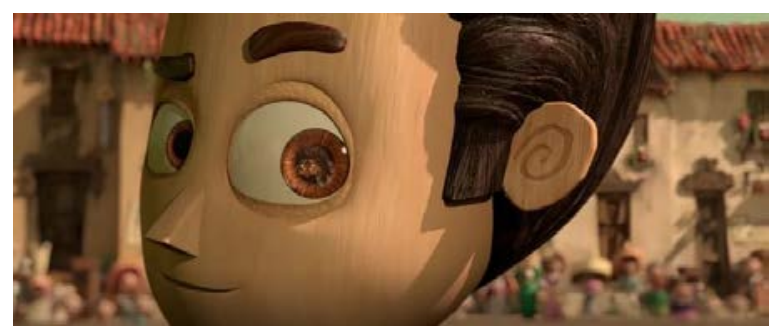

Manolo's CU shot with the hog's reflection in his eye (TBOL, 2014: 00:14:26).

This mise-en-scène focuses on Manolo's face as he sees the hog only by turning his head slightly to the left. The reflection of the hog and the expression Manolo is making shows that he indulges the Give 'Em Hell theme particularly on daring himself to face the hog head-on. As it has been discussed in part $\mathrm{A}$, this mise-enscène is set after Joaquin saves General Posada from the raging hog that charges towards the town hall. Moments after taking the hog's impact, Joaquin looks over to Manolo and he begins to taunt the hog. The first taunt goes smoothly and Carlos sees this as a sign that he "has the gift."

After the hog incident is over, the first shot of the bullring is shown after Manolo and Carlos stops their walk at the end of a fence. The initial shot of the arena is set 180 degree to give the sense of continuous space over a location.

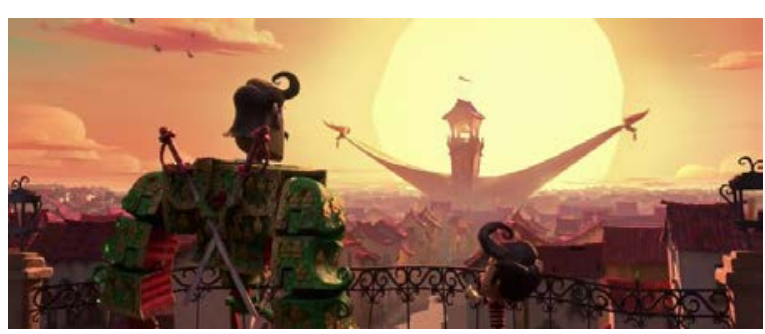

Carlos (left) and Manolo (left) looking at the arena with a sunset behind it

(TBOL, 2014: 00:16:39).

This mise-en-scène is the first step for Carlos to shape Manolo to become a proper man. In this shot, the father-and-son relationship is bonded through hegemonic masculinity that Carlos applied to Manolo after he witness Manolo's triumph over the hog. In this particular setting as well, Carlos talks about the tradition of bullfighting the Sanchez family have. The arena scene is the first masculine nuances in The Book of Life because in this mise-en-scène Carlos tells Manolo the glory and the honour of being a Sanchez bullfighter. In here, the atmosphere of The Big Wheel theme is shown.

By showing Manolo the arena, Carlos shows him the success of being a bullfighter really is.

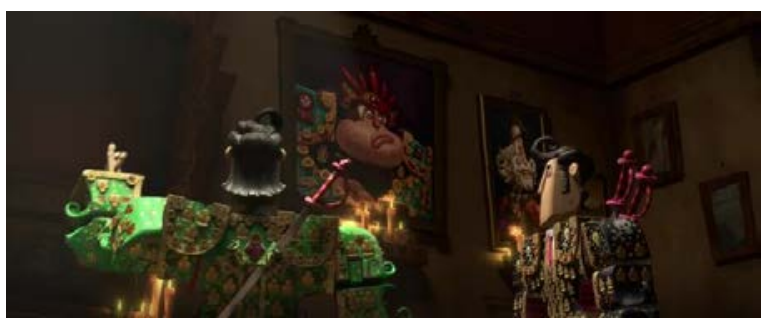




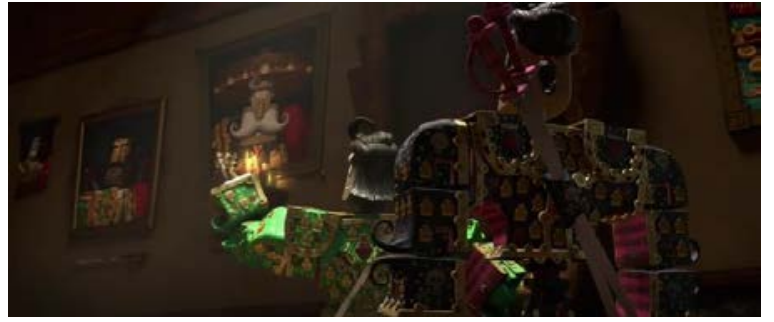

The 180-degree rule from the right to left, following Carlos's hand movement. (TBOL, 2014: 00:21:11 - 00:21:18)

The next mise-en-scène is when Manolo gets lectured by Carlos about the importance of becoming a Sanchez bullfighter. In here, Carlos shows Manolo pictures of Sanchez bullfighters hanging on a wall. Using the 180degree rule, this time the camera moves side to side (pan) from right to left to give the sense of flowing images in line with Carlos's hand gesture.

By using the MS, the 180-degree movement is coherent with Carlos's hand movement and gives the sense of The Big Wheel theme. The nuance of success and status are reflected in this mise-en-scène when Carlos says, "All the Sanchezes are bullfighters. Every single one of us." The view of the hanging pictures of Sanchez bullfighters showcases the example of what Manolo should have become in his life. In this image as well, Carlos states his point to Manolo about the honour of becoming a Sanchez bullfighter.

Manolo disagrees with Carlos's notion of bullfighting. He believes that killing a bull is wrong and this goes beyond comprehension for Carlos. Moments before Manolo is leaving the room, Carlos utters, "Don't you love your family? Then go get that bull mijo. Don't dishonour our name." This gives Manolo cold feet as he hands over Carlos his guitar and left the room.

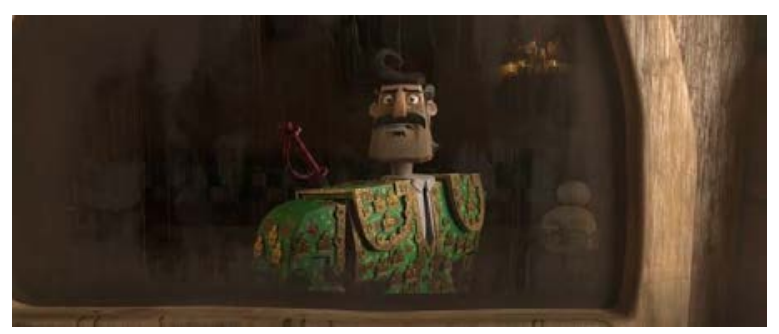

Carlos utters "Just be a Sanchez."

(TBOL, 2014: 00:22:15).
As Manolo leaves the room, Carlos reminds him to "be a Sanchez". This is the notion that has been discussed earlier in part A, where the word "Sanchez" refers itself to Pleck's Male Sex Role Identity. Using the MCU shot, the figure of Carlos displays his anxiety and concern towards Manolo to obey his command. In patriarchal sense, a social unit (a family or tribe, for example) is ruled by the male head. The patriarch, typically a societal elder, has legitimate power over others in the social unit, including other (especially younger) men, all women and children (Pilcher \& Whelehan, 2004, p. 93).

After meeting Joaquin, Manolo enters the corrida and the bull enters as well. Manolo faces the beast and taunts the beast while Carlos still exhibits hesitation in his face. Clenching his fist while leaning on a fence demonstrates his anxiety and hesitation towards Manolo's first match.

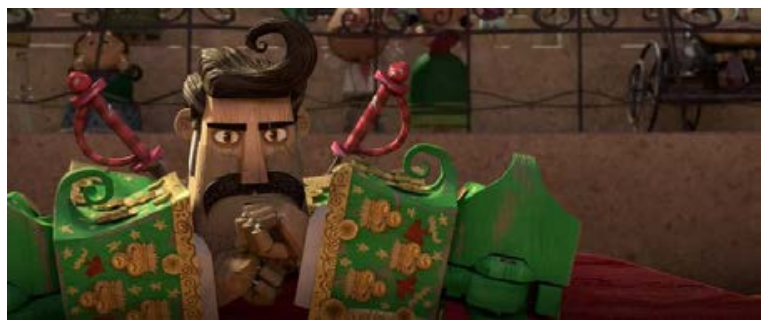

Carlos clenches his fist in this MCU shot (TBOL, 2014: 00:25:06).

Carlos's stern look expresses his worries whether the match will end the way he perceived or will it be a total chaos. As the show begins with Manolo taunting the bull, the crowd is impressed by his performance. The match goes smoothly that even Carlos shows his happiness with a smile. In this scene, Manolo develops his obsessive competitiveness because of Joaquin's presence.

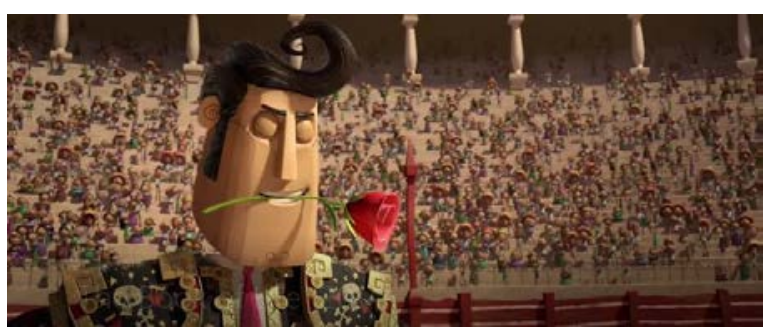

Manolo bites the stem of a rose (TBOL, 2014: 00:25:38). 
The scent of toughness is presented in the next mise-en-scène where Manolo somersaults a bull that is coming from behind. The somersault enables Manolo to evade the bull. This also shows his strength as a Sanchez bullfighter. The mise-en-scène evokes confidence in Manolo as he bites the stem of a rose from which he carried before the bull approaches him. The mise-en-scène uses CU shot to show Manolo's confidence he goes on taunting the bull. The crowd yells olé for each of Manolo's bold moves against the bull. The peak of the match starts when Carlos giving Manolo a sword wrapped in red sheets.

Carlos utters "Come on mijo. For me. For our family. Be a Sanchez!" to Manolo in this mise-en-scène. Essentially, Carlos stresses Manolo on "being a Sanchez" precisely in this mise-en-scène where raises the sword and gives it to Manolo. Before the 180-degree shot is applied, the men's conversation is taken in shot/reverse shot.

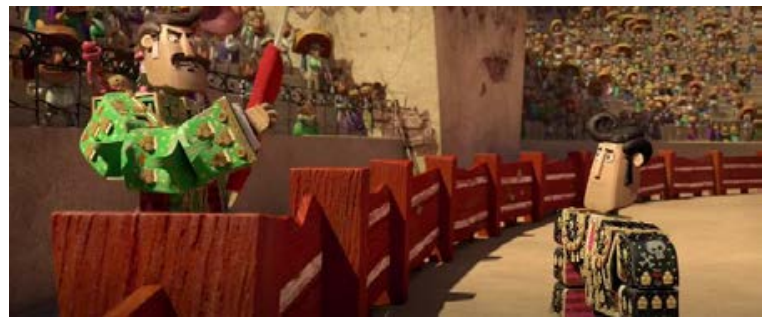

Carlos stresses the sentence "Be a Sanchez" to Manolo (TBOL, 2014: 00:26: 16)

This technique is used to show the relation and the flow of a conversation between two persons with vice versa perspectives. On Manolo's mise-en-scène, he looks at Carlos with an uncertain facial expression. On the other hand, Carlos looks at Manolo with concern and hope that Manolo will not mess up the match. This flow of conversation also uses the 300 spatial view to illustrate that the camera is moving in a pan motion but does not step over the imaginary line. The shot/reverse shot starts with the MCU shot of Manolo then goes to Carlos with CU shot and ends with MS of the men in 30 o shot.

The next sequence of the shots illustrates the notion of "the need to be looked up to". By being strict, Carlos diminishes Manolo's homosexual masculinity so that he can ensure Manolo's future as the greatest Sanchez bullfighter ever. Another notion that is evoked in this mise-en-scène is the presence of being aggressive and violence. The notion presented here are from Carlos's initiative for Manolo to become as fierce as the bull, even precedes it.
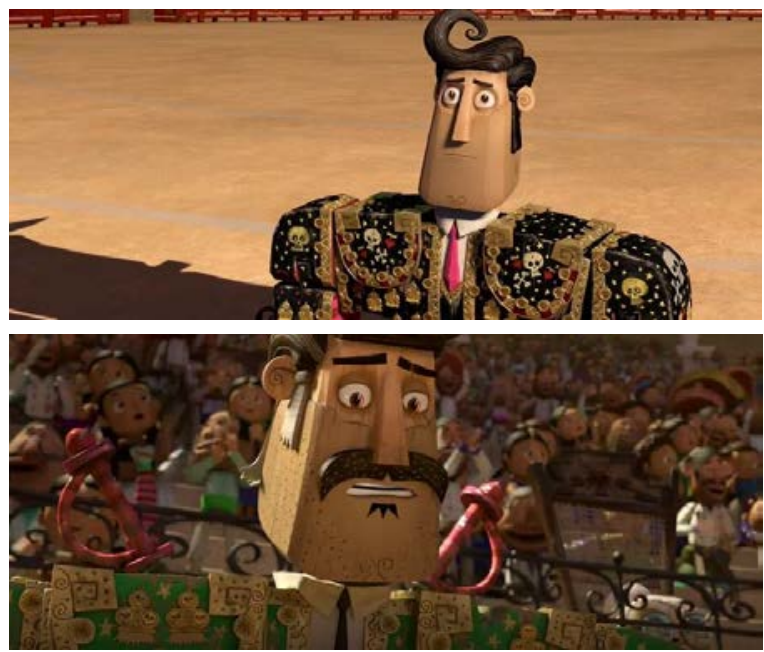

The shot/reverse shot technique between Manolo and Carlos

(TBOL, 2014: 00:26:11 - 00:26:13)

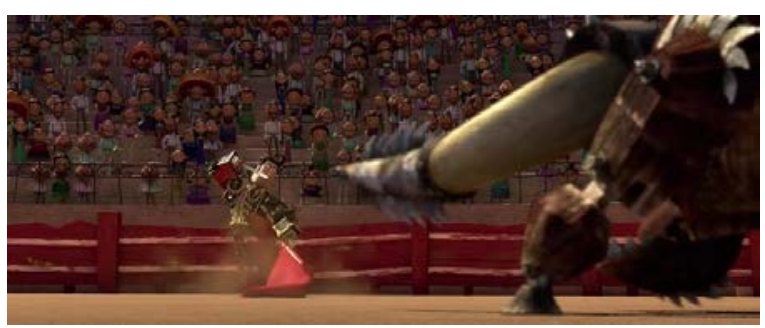

Manolo faces the bull with a sword (TBOL, 2014: 00:26:22).

The next mise-en-scène shows the peak of the show where Manolo is expected to stab the bull to the heart. In this part, the 180-degree rule is applied but preceding this shot is a jump cut. A jump shot is used whenever a shot is added but does not coherent with the overall shots. Before Manolo prepares his sword in this scene, a shot of Maria's face is added right before Manolo draws his sword onto the ground. This creates a gap between the shots as this eliminates the spatial continuity.

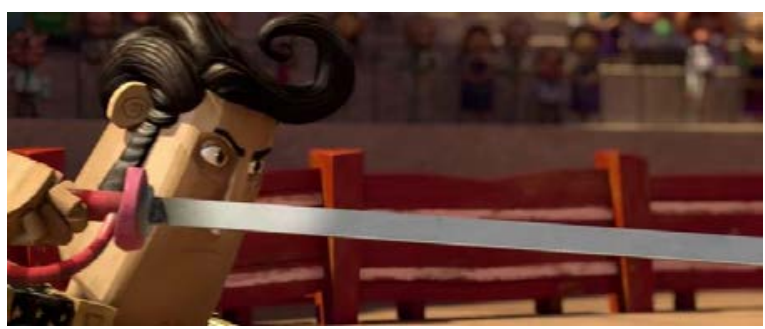




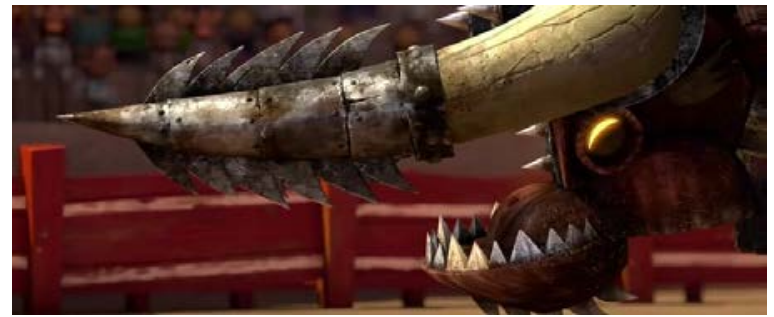

The 180-degree shot and CU shot of Manolo's sturdy face as he holds the sword firmly towards the bull's jagged form

(TBOL, 2014: 00:26:25 - 00:26:28)

As Manolo holds his sword steadily towards the angry bull, the camera pans itself from the right side (the edge of Manolo's sword) to the left (Manolo's face) and from the left side (the tip of the bull's horn) to the right (the bull's whole face and spiked thorns). The CU shots add the sense of thrill in the corrida and in the crowd.

The next part of the mise-en-scène relies solely on the jump cut that continues from the prior shots. After the 180o shot of Manolo and the bull, the jump cut starts with the shot of Father Domingo and the Sisters, Carlos, and finally Maria until finally comes back to the bull then Manolo.

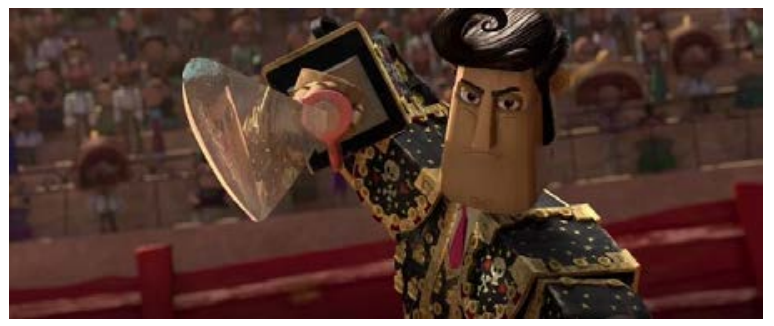

Manolo's fearsome gaze on the MCU shot in front of him (TBOL, 2014: 00:26:32).

By having the MCU shot from the front, it can be seen that Manolo's expression is serious yet uncertain. His masculinity is at stake and many watches him hoping that he killed the bull. This represent the idea of "the need to be looked up to", aggression, and toughness. In this mise-en-scène, Manolo positions himself as the embodiment and the extension of Carlos. The four themes of Pleck's Male Sex Role Identity is explored in this mise-en-scène. However, not all parts of Carlos are there since the next mise-en-scène reveals why Manolo spoiled the match.

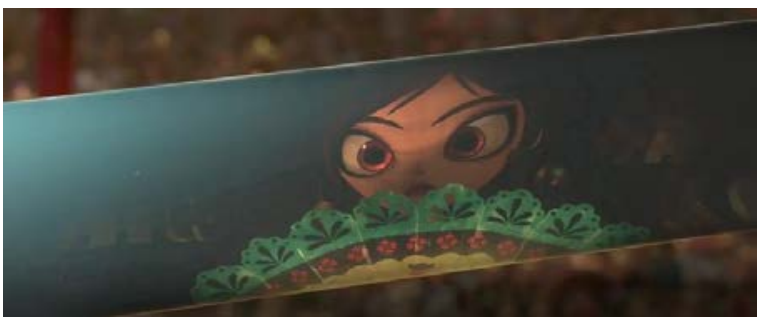

Maria's reflection on Manolo's sword

(TBOL, 2014: 00:26:37)

The reflection of Maria's face on Manolo's sword stops him from doing the thing he displease the most; killing a bull. The ECU shot gives sense to viewers what Manolo sees on his sword. The nature of ECU shot is to give the viewers a point-of-view of what the character is seeing.

\section{Conclusion}

Manolo's masculine characteristics predominantly lies on Male Sex Role Strain, hegemonic masculinity, and imposed environment. The way Manolo escapes the imposed environment is through a selected environment that is also a part of constructed environment though is not enough to consider it as "masculine" enough. Joaquin's masculine characteristics dominates the Male Sex Role Identity in all four themes. Though prefer to be in a selected environment, the environment itself is a part of a constructed environment that acknowledge Joaquin's selected environment. His masculinity also stands out in the hegemonic masculinity most of time.

Carlos's masculine characteristics are a part of the old notion of manly man. By being strict to Manolo, his masculine characteristics are based upon obsessive competitiveness, Pleck's Male Sex Role Identity, hegemonic masculinity, and constructed environment.

The various mise-en-scène shows the facial expressions of Manolo and Carlos predominantly on the scene where the activity of bullfighting is occurred. The facial expressions relate the characters' feeling and emotions. The framing language shows that the camera's movement in Jorge Gutierrez's The Book of Life is taken dominantly between the MS and the ECU shot. These give the aura of masculinity in the characters and the focus 
for the viewer to see what the characters are looking at. The continuity editing shows that the spatial setting in The Book of Life uses the $180 \mathrm{o}$ Rule to show the masculine characteristics where the dominant male is cheered by his spectators. Shot/Reverse Shot is also used to give the sense of feedback in conversations and jump shot is applied to give the thrill of bullfighting in The Book of Life.

\section{References}

Benyahia, Sarah Casey, Freddie Gaffney, and John White. As Film Studies: The Essential Introduction. Oxford: Routledge, 2006.

Bird. Sharon R. "Welcome to the Men's Club: Homosociality and the Maintenance of Hegemonic Masculinity". Gender and Society. Vol. 10. No. 2 (1996): p. 120-132. SAGE. (www.jstor.org/stable/189829). October 6, 2016.

Boggs, Joseph M. The Art of Watching Films. Menlo Park: The Benjamin/Cummings Publishing Company, Inc. 1978.

Brannon, Linda. Gender: Psychological Perspectives. Needham Heights: A Simon \& Schuster Company, 1996.

Buckland, Warren. Film Studies. London: Hodder Headline Plc., 1998.

Bussey, Kay and Albert Bandura. "Social Cognitive Theory of Gender Development and Differentiation". Psychological Review, 106, 676-713. 1999.

Butler, Andrew M. Film Studies. Harpenden: Pocket Essentials, 2005.

Dubbert, Joe L. A Man's Place: Masculinity in Transition. Englewood Cliffs: PrenticeHall, Inc., 1979.

Elsaesser, Thomas and Warren Buckland. Studying Contemporary American Film: A Guide to Movie Analysis. London: Arnold Publishing, 2002.
Gutierrez, Jorge R. The Book of Life. FMOVIES. FMOVIES. 2014.

(www.fmovies.se/film/the-book-oflife.jvpn). September 8, 2016.

Krismanto. Wahyu J.C. "Hemingway's Views on Masculinity and Men's Relationship as Reflected through the Characters of Jack Barnes and Robert Cohn in The Sun Also Rises". Undergraduate Thesis. Yogyakarta: Sanata Dharma University, 2004.

Moore, Colin. "Of Men and Bulls: The Spanish Tradition of Bullfighting." Verge. August 7, 2009. Verge Magazine. (www.vergemagazine.com). September $29,2016$.

Pilcher, Jane and Imelda Whelehan. Fifty Key Concepts in Gender Studies. London: SAGE Publications Ltd., 2004.

Pleck, Joseph H. and Jack Sawyer. Men and Masculinity. Englewood Cliffs: PrenticeHall, Inc., 1974.

Salisbury, Jonathan and David Jackson. Challenging Macho Values: Practical Ways of Working with Adolescent Boys. Bristol: The Falmer Press, 2004.

Swarupa. "Bullfighting in Mexico". Swarupa's World - A Wonderful World Full of Beauty, Charm, and Adventure. WordPress.com. October 10, 2013. (www.thegr8wall.wordpress.com). September 29, 2016.

The Book of Life (2014) Movie Script. Springfield! Springfield!. n.p. n.d. (http://www.springfieldspringfield.co.uk /movie_script.php?movie=the book-oflife). October 1, 2016.

Villarejo, Amy. Film Studies: The Basics. Oxford: Routledge, 2007. 